\title{
ARTIKELEN
}

\section{Crimmigratie en bestuursrechtelijke criminologie: verwante concepten of verschillende disciplines?}

\author{
Benny van der Vorm
}

\section{$1 \quad$ Inleiding}

Met de opkomst van de bestuurlijke boete in het begin van de jaren negentig van de vorige eeuw heeft het bestuurlijke sanctierecht een belangrijke plaats verworven in de publiekrechtelijke rechtshandhaving. Zo kan worden gewezen op de rol van het bestuursrecht ten aanzien van de handhaving van financieel-economische wetgeving, ${ }^{1}$ de aanpak van organisatiecriminaliteit, ${ }^{2}$ georganiseerde $\operatorname{misdaad}^{3}$ en het immigratierecht. Veel soorten misdaad worden zowel preventief als repressief bestreden middels de integrale aanpak. Hiermee wordt bedoeld dat een bepaalde vorm van misdaad niet uitsluitend wordt aangepakt door middel van de inzet van het strafrecht, maar dat ketenpartners met elkaar samenwerken en sprake is van een combinatie van strafrechtelijke, bestuurlijke, financiële en/of sociale maatregelen. In dit verband kan worden gewezen op de integrale aanpak van het migratievraagstuk. Het doel is om migratie veilig en gecontroleerd te laten verlopen, onder meer door een nauwe samenwerking tussen de ketenpartners.

De integrale aanpak van het migratievraagstuk laat zien dat het strafrecht en het immigratierecht niet afzonderlijk van elkaar kunnen worden gezien en dat de scheiding tussen beide domeinen lijkt te vervagen. ${ }^{4}$ Een vergelijkbare ontwikkeling heeft zich voorgedaan in de Verenigde Staten van Amerika en heeft geleid tot de introductie van het begrip 'crimmigratie'. ${ }^{5}$ Ook in Nederland heeft deze term voet aan de grond gekregen. Vanuit een wetenschappelijk perspectief is het van belang om voor ogen te houden wat crimmigratie nu precies behelst. Is crimmigratie gericht op de juridische aspecten van een verstrengeling tussen strafrecht en immigratierecht? Met andere woorden: is vooral sprake van 'bestuursstraf-

1 Zie bijvoorbeeld A.G. Mein, De boete uit balans. Het gebruik van de bestuurlijke boete in de praktijk van het financieel toezicht (diss. Rotterdam), Den Haag: Boom Juridische uitgevers 2015.

2 Zie bijvoorbeeld J.J.H. Beckers, Tussen ideaal en werkelijkheid. Een empirische studie naar de strafrechtelijke aanpak van organisatiecriminaliteit in Nederland (diss. Rotterdam), Rotterdam: Erasmus Universiteit Rotterdam 2017.

3 Zie bijvoorbeeld B. van der Vorm, Ernstig gevaar. Een juridisch-empirisch onderzoek naar aard, doel en toepassing van de Wet Bibob (diss. Tilburg), Oisterwijk: Wolf Legal Publishers 2016.

4 M.A.W. van der Woude, 'Crimmigratie: What's in a word?', Crimmigratie \& Recht 2018, p. 3.

5 J. Stumpf, 'The crimmigration crisis: Immigrants, crime and sovereign power', American University Law Review 2006, p. 367-419. 
recht'? ${ }^{6}$ Of omvat crimmigratie eveneens de sociaalwetenschappelijke bestudering van het immigratie- en strafrecht? Deze vragen zijn van belang, indien een vergelijking wordt gemaakt met de recentelijk geïntroduceerde deeldiscipline 'bestuursrechtelijke criminologie'. ${ }^{7}$ Vanuit een wetenschappelijk perspectief is het belangwekkend om beide concepten met elkaar te vergelijken en te bezien in hoeverre sprake is van een overlap tussen beide, omdat op het eerste gezicht beide veel met elkaar gemeen lijken te hebben.

In deze bijdrage staat de volgende onderzoeksvraag centraal: 'Wat zijn de overeenkomsten en verschillen tussen crimmigratie en bestuursrechtelijke criminologie en op welke wijze kunnen zij elkaar aanvullen?' Teneinde deze vraag te kunnen beantwoorden, wordt vooreerst in het kort uitgelegd wat het doel van een vergelijking tussen crimmigratie en bestuursrechtelijke criminologie is (paragraaf 2), waarna vervolgens het begrip crimmigratie nader wordt verkend, zodat duidelijk wordt wat dit begrip precies behelst (paragraaf 3 ). Ten derde wordt de reikwijdte van de bestuursrechtelijke criminologie in kaart gebracht (paragraaf 3 ). In de vijfde paragraaf volgt de synthese (paragraaf 5 ), waarna beide concepten worden toegelicht aan de hand van een belangwekkende bestuurlijke maatregel, namelijk de intrekking van het Nederlanderschap in het belang van de nationale veiligheid (paragraaf 6). Er wordt besloten met een conclusie (paragraaf 7).

\section{Het doel van een vergelijking tussen crimmigratie en bestuursrechtelijke criminologie}

De tijd dat het recht uitsluitend kon worden bestudeerd vanuit de 'eigen' juridische discipline behoort voor een belangrijk deel tot het verleden. In toenemende mate wordt van rechtswetenschappers verwacht dat zij inzicht en kennis hebben van sociaalwetenschappelijk onderzoek en de resultaten ook kunnen 'vertalen' naar juridisch onderzoek. Een stroming die steeds meer aan belang wint is de stroming van de 'Empirical Legal Studies' (hierna: ELS). Inmiddels is in de literatuur veel aandacht besteed aan ELS en de gevolgen hiervan voor het juridische onderzoek in Nederland. ${ }^{8}$ Tegen deze achtergrond is het dan ook niet verwonderlijk dat onlangs de 'Werkgroep Rechtswetenschap' is opgericht om een platform te bieden voor een nadere bezinning over de taak en inhoud van de rechtswetenschap. ${ }^{9}$ In de afgelopen periode lijken verschillende subdisciplines zich te hebben ontwikkeld, die zich thematisch - althans in grote lijnen - op dezelfde onderwerpen richten. In het oog springen de volgende wetenschappelijke disciplines: de ELS, de geïntegreerde strafrechtswetenschap, de bestuursrechtelijke criminologie

6 Vgl. A.R. Hartmann \& P.M. van Russen Groen, Contouren van het bestuursstrafrecht (diss. Rotterdam), Arnhem: Gouda Quint 1998.

7 B. van der Vorm, Bestuursrechtelijke criminologie. Een verkenning naar de relatie tussen criminologie en bestuursrecht, Den Haag: Boom juridisch 2018.

8 Zie bijvoorbeeld N. Elbers, M. Malsch, P. van der Laan, A. Akkermans \& C. Bijleveld, 'Empirischjuridisch onderzoek in Nederland. Bespiegelingen over de stand van zaken in de rechtswetenschap, het juridisch onderwijs en de rechtspraktijk', Recht der Werkelijkheid 2018, p. 30-42.

9 Zie https://werkgroeprechtswetenschap.nl. 
en de crimmigratie. Indien de crimmigratie als uitgangspunt wordt genomen, is een nadere afstemming tegenover deze andere disciplines bepaald geen overbodige luxe. Richten al deze disciplines zich niet op hetzelfde object? Het antwoord op deze vraag luidt ontkennend. Hoewel de ELS, de geïntegreerde strafrechtswetenschap en de bestuursrechtelijke criminologie raakvlakken hebben, bestaan er ook grote verschillen. In het concept van de geïntegreerde strafrechtswetenschap is sprake van een integratie tussen de criminologische wetenschap en de strafrechtswetenschap. ${ }^{10}$ In de visie van Fijnaut is sprake van de toepassing van de geïntegreerde strafrechtswetenschap, indien 'grondgedachten, of themata uit verschillende wetenschapsdomeinen tot een zinvol geheel worden gemaakt, worden ondergebracht in een beredeneerd verwachtingspatroon, dat vervolgens het probleemoplossend handelen kan informeren en sturen. ${ }^{11}$ Deze eis ligt niet besloten in de ELS noch in de bestuursrechtelijke criminologie, omdat deze disciplines geen integratie tussen criminologie en (straf)rechtswetenschap voorstaan. De ELS, de bestuursrechtelijke criminologie en de crimmigratie hebben als overeenkomst dat ze alle gericht (kunnen) zijn op de empirie van het immigratierecht. Op het eerste gezicht lijkt er een grote overlap te bestaan tussen de crimmigratie en de bestuursrechtelijke criminologie. Zijn beide disciplines nu inhoudelijk identiek? Of bestaan er belangrijke verschillen? Zeker gezien de opkomst van op het eerste gezicht verwante disciplines is - vanuit een wetenschappelijk perspectief een nadere verkenning van de bestuursrechtelijke criminologie en de crimmigratie onontbeerlijk. Het doel van deze exercitie is om zowel de crimmigratie als de bestuursrechtelijke criminologie disciplinair te duiden.

\section{Het begrip crimmigratie nader verkend}

In dit tijdschrift is onlangs door Van der Woude aangegeven wat onder de term 'crimmigratie' wordt verstaan. De term 'crimmigratie' is in Nederland in 2010 geïntroduceerd door Van der Leun. ${ }^{12}$ Het crimmigratierecht is gebaseerd op drie pijlers. Ten eerste wordt gewezen op de gevolgen van het strafrecht voor het immigratierecht: een toename van gepleegde strafbare feiten kan immigratierechtelijke gevolgen hebben, zoals verwijdering. Ten tweede kan, volgens Van der Woude, crimmigratie wijzen op de strafbaarstelling van immigratierechtelijke omstandigheden, waarbij kan worden gewezen op de discussie omtrent de strafbaarstelling van illegale vreemdelingen. Ten slotte heeft crimmigratie betrekking op de uitvoeringspraktijk van het immigratierecht. De strafrechtelijke praktijk van bijvoorbeeld detentie kan ter inspiratie dienen. ${ }^{13}$

De eerste twee pijlers zijn juridisch van aard, terwijl de derde pijler meer gericht is op de empirie, namelijk de werking van het straf- en immigratierecht. Dit suggereert dat het concept crimmigratie zowel juridisch als empirisch van aard is.

10 Van der Vorm 2018, p. 101.

11 C. Fijnaut, Verleden, heden en toekomst van de geïntegreerde strafrechtswetenschap (oratie Rotterdam), Arnhem/Antwerpen: Gouda Quint 1986, p. 78.

12 J.P. van der Leun, Crimmigratie, Apeldoorn/Antwerpen: Maklu-Uitgevers 2010.

13 Van der Woude 2018, p. 4-5. 
Dit wordt eveneens opgemerkt door Van der Woude. Crimmigratie komt van oorsprong uit de juridische discipline, maar gaandeweg heeft dit concept ook de weg gevonden in empirische disciplines, zoals de sociologie, de criminologie en de politicologie. Die ontwikkeling heeft ertoe geleid dat de drie pijlers op een empirische wijze kunnen worden bestudeerd. ${ }^{14}$ Het is echter onmogelijk om aan te geven waar de nadruk in het concept van crimmigratie ligt. Is het vooral een juridisch begrip? Of juist een empirisch concept? Vanuit een disciplinair perspectief is het relevant om een dergelijke vraag op te werpen. Sommige auteurs neigen de crimmigratie als een empirisch concept te duiden. Zo ziet Franko de crimmigratie niet zozeer als een concept dat de nadruk legt op de vervlechting tussen strafrecht en immigratie, maar zij benadrukt vooral het vervagen van de grenzen tussen criminaliteitscontrole en de controle op de migratie. ${ }^{15}$ In de kern komt crimmigratie neer op 'het door wetgeving, beleid en tenuitvoerlegging verwikkeld raken van vreemdelingentoezicht en criminaliteitsbeleid. ${ }^{16}$ Crimmigratie is hiermee een concept dat zowel is gericht op juridische aspecten (vervlechting strafrecht en immigratie) alsook op empirische aspecten (vervlechting tussen vreemdelingentoezicht en criminaliteitsbeleid). In dat opzicht vertoont crimmigratie veel overeenkomsten met het reeds door Fijnaut voorgestane concept van de geïntegreerde strafrechtswetenschap. ${ }^{17}$ Zowel de crimmigratie als de geïntegreerde strafrechtswetenschap zijn interdisciplinaire concepten. Crimmigratie lijkt een bijzondere vorm te zijn van geïntegreerde strafrechtswetenschap.

\section{De reikwijdte van de bestuursrechtelijke criminologie}

\subsection{Inleiding}

De criminologie als zelfstandige wetenschappelijke discipline is gericht op vijf aandachtsgebieden, namelijk de beschrijvende criminologie (criminografie), de etiologie (leer van de oorzaken), criminaliteitspreventie (als reactie), penologie (leer van de straffen) en de victimologie (slachtofferkunde). Van oudsher is 'de' criminologie gericht op het strafrecht, maar met de opkomst van het bestuurlijke sanctierecht zijn meer criminologen zich eveneens gaan richten op de werking van bestuurlijke sancties. ${ }^{18}$ Mijns inziens kunnen drie hoofdvelden worden onderscheiden, waarbij het bestuursrecht wordt bezien vanuit een criminologisch perspectief, namelijk de bestuursrechtelijke criminologie, de bestuursrechtelijke victimologie en de bestuursrechtspleging. Naar mijn mening kan de bestuursrechtelijke criminologie worden gedefinieerd als 'een empirische wetenschap, die zich bezighoudt met de wijze waarop de bestuursorganen toepassing geven aan de

14 Van der Woude 2018, p. 5.

15 K. Franko, 'Crimmigrant Bodies and Bona Fide Travelers: Surveillance, Citizenship and Governance', Theoretical Criminology 2011, p. 331-346.

16 Van der Woude 2018, p. 6.

17 C.J.C.F. Fijnaut, Verleden, heden en toekomst van de geïntegreerde strafrechtswetenschap (oratie Rotterdam), Arnhem: Gouda Quint 1986.

18 Zie bijvoorbeeld C.G. van Wingerde, De afschrikking voorbij. Een empirische studie naar afschrikking, generale preventie en regelnaleving in de Nederlandse afvalbranche (diss. Rotterdam), Oisterwijk: Wolf Legal Publishers 2012. 
bestuursrechtelijke handhaving. ${ }^{\text {'19 }}$ De bestuursrechtelijke criminologie en penologie zijn, zoals later zal blijken, sterk met elkaar verbonden. Dit geldt in mindere mate voor de bestuursrechtelijke victimologie. In deze deeldiscipline staat het slachtoffer in de bestuurlijke procedure centraal. De deeldiscipline bestuursrechtspleging richt zich voornamelijk op de werkwijze van de bestuurlijke actoren en vertoont raakvlakken met de bestuurskunde. Het grote verschil tussen de bestuursrechtelijke criminologie en de bestuursrechtspleging is dat in laatstgenoemde de actor vooral centraal staat en in de bestuursrechtelijke criminologie vooral de (toepassing van de) sanctie. In deze bijdrage zal uitsluitend aandacht worden besteed aan wat is voorgesteld als de bestuursrechtelijke criminologie.

\subsection{De bestuursrechtelijke criminologie: What's in name? ${ }^{20}$}

Uit de gegeven definitie van bestuursrechtelijke criminologie blijkt ten eerste dat de bestuursrechtelijke criminologie is gericht op de bestuursrechtelijke handhaving. Hieronder vallen alle bestuursrechtelijke sancties: de last onder dwangsom, de last onder bestuursdwang, de bestuurlijke boete en de intrekking van een begunstigende beschikking. Daarnaast vallen eveneens bestuursrechtelijke maatregelen onder het bereik van de bestuursrechtelijke criminologie. Men denke onder andere aan het sluiten van panden of woningen, ${ }^{21}$ de bestuurlijke ophouding, ${ }^{22}$ het opleggen van een huisverbod op grond van de Wet Tijdelijk Huisverbod, ${ }^{23}$ de weigering of intrekking van een beschikking op grond van de Wet Bibob $^{24}$ en persoonsgericht verstoren. ${ }^{25}$ Een strikte - maar juridisch wel juiste toepassing van deze definitie leidt ertoe dat de bestuurlijke strafbeschikking niet valt onder het bereik van de bestuursrechtelijke criminologie, omdat de bestuurlijke strafbeschikking nu eenmaal niet is aan te merken als bestuursrecht, maar als strafrecht. ${ }^{26}$ De bestuurlijke detentie - als bestuurlijke maatregel - valt daarentegen wel onder het bereik van de bestuursrechtelijke criminologie. ${ }^{27}$

De bestuursrechtelijke criminologie is gericht op de empirie van de bestuursrechtelijke rechtshandhaving. Dit betekent geenszins dat dit vakgebied geen oog heeft voor relevante ontwikkelingen in aangrenzende vakgebieden. Reeds is gewezen op de bestuurlijke strafbeschikking. Naast de bestuurlijke boete bestaat dus ook

19 Van der Vorm 2018, p. 91.

20 Deze subparagraaf is gebaseerd op Van der Vorm 2018, p. 91.

21 Zie bijvoorbeeld J.G. Brouwer \& A.E. Schilder, 'Woonoverlast en de persoonlijke levenssfeer. Naar een balans tussen bescherming en beperking', NJCM-bulletin 2011, p. 307-324.

22 Zie bijvoorbeeld M.A.D.W. de Jong, 'Bestuurlijke ophouding: Lelijk eendje voor het leven', NJCMbulletin 2003, p. 962-978.

23 Zie bijvoorbeeld K. Lünnemann, R. Römkens \& Th. de Roos, 'Wie slaat, die gaat! Kanttekeningen bij het huisverbod als nieuw instrument in de aanpak van geweld achter de voordeur', NJB 2009, p. 940-946.

24 Zie bijvoorbeeld B. van der Vorm, Ernstig gevaar. Een juridisch-empirisch onderzoek naar aard, doel en toepassing van de Wet Bibob (diss. Tilburg), Oisterwijk: Wolf Legal Publishers 2016a.

25 Zie bijvoorbeeld J.G. Brouwer, Van nachtbrakers tot terroristen. Over persoonsgericht verstoren (oratie Groningen), Groningen 2006.

26 Zie bijvoorbeeld A.R. Hartmann, 'De bestuurlijke strafbeschikking: panacee voor de gemeentelijke handhaving?', Proces 2010, p. 64-75.

27 Zie bijvoorbeeld T. Kooijmans \& P.A.M. Mevis, 'Bestuurlijke detentie’, NTB 1999, p. 109-117. 
de bestuurlijke strafbeschikking (ex 257ba Sv). De bestuurlijke strafbeschikking kan worden uitgevaardigd door een aantal lichamen en personen, met een publieke taak belast, zoals de Inspectie Leefomgeving en Transport. Het grote verschil met de bestuurlijke boete is dat de bestuurlijke strafbeschikking wordt ingezet als er sprake is van een strafrechtelijke overtreding. Verzet hiertegen wordt daarom aangetekend bij het Openbaar Ministerie. Het moge duidelijk zijn dat de bestuursrechtelijke criminologie eveneens is geïnteresseerd in de (empirie van de) bestuurlijke strafbeschikking, omdat de bestuurlijke strafbeschikking wordt opgelegd door bestuurlijke entiteiten.

De empirie van de bestuursrechtelijke handhaving is ruim. Onderzoek naar de effectiviteit van bestuurlijke boetes is een voorbeeld van de bestuursrechtelijke penologie. Onderzoek naar slachtofferschap van het bestraffende bestuur is een voorbeeld van de bestuursrechtelijke victimologie. Ook kan worden gedacht aan empirische studies naar de werking van de Wet tijdelijk huisverbod in de praktijk. ${ }^{28}$ Uit het voorgaande kan wellicht de indruk ontstaan dat de empirie van de bestuursrechtelijke criminologie uitsluitend is gericht op de werking van bestuurlijke handhavingsmechanismen en/of bestuurlijke sancties. Dit is inderdaad het geval; empirisch onderzoek naar aard en omvang van misdaad, die door de bestuurlijke instanties wordt bestreden, valt niet onder het bereik van de bestuursrechtelijke criminologie, maar veeleer onder de bestuurlijke criminologie. Het is evident dat juridische studies over de bestuursrechtelijke handhaving, inclusief het bestraffende bestuursrecht, eveneens van belang zijn voor de bestuursrechtelijke criminologie. ${ }^{29}$

\subsection{De geïntegreerde strafrechtswetenschap, de bestuursrechtelijke criminologie en de bestuursrechtelijke penologie $e^{30}$}

De bestuursrechtelijke criminologie is een empirische wetenschap en is voortgekomen uit de 'administrative criminology'. ${ }^{31}$ Deze bijzondere vorm van criminologie vertoont ook verwantschap met het door Fijnaut ontwikkelde concept van de geïntegreerde strafrechtswetenschap. Fijnaut heeft aangegeven dat het niet eenvoudig is gebleken om publicaties te laten verschijnen waarin de dynamische wisselwerking tussen het strafrecht en de criminologie centraal staat. $^{32}$ Dit geldt nog meer ten aanzien van onderzoek naar de (toepassing van)

28 Zie bijvoorbeeld K. de Vaan, A. Schreijenberg, G. Homburg \& J. Schilder, Knelpunten in de uitvoering van de Wet tijdelijk huisverbod, Amsterdam: Regioplan Beleidsonderzoek 2013.

29 Zie bijvoorbeeld F.C.M.A. Michiels, A.B. Blomberg \& G.T.J.M. Jurgens, Handhavingsrecht. Handboeken Staats- en Bestuursrecht, Deventer: Wolters Kluwer 2016; C.L.G.F.H. Albers, 'Bestraffend bestuur 2014. Naar een volwassen bestraffend bestuurs(proces)recht?', in: Boetes en andere bestraffende sancties: een nieuw perspectief? (Preadviezen VAR 2014), Den Haag: Boom Juridische uitgevers 2014, p. 7-108.

30 Deze subparagraaf is gebaseerd op Van der Vorm 2018, p. 132-133.

31 De stroming 'Administrative Law \& Society' kan in dit verband niet onvermeld blijven. De bestudering van het bestuursrecht is immers ook van belang binnen de rechtssociologie.

32 C.J.C.F. Fijnaut, 'De waarde van de geïntegreerde strafrechtswetenschap: een gevalstudie', in: R.M.G.E. Foqué (red.), Geïntegreerde rechtswetenschap. Opstellen geschreven ter gelegenheid van het dertigjarig bestaan van de Faculteit der Rechtsgeleerdheid van de Erasmus Universiteit Rotterdam 1963-1993, Arnhem: Gouda Quint 1994, p. 344. 
bestuursrechtelijke handhandhavingsinstrumenten en bestuursrechtelijke sancties in de praktijk. Veelal is het onderzoek uitsluitend van juridische aard ${ }^{33}$ of uitsluitend van empirische aard. ${ }^{34}$ Onderzoeken die zijn gericht op zowel een bestuursrechtelijke als empirische analyse van de toepassing van de bestuursrechtelijke instrumenten, zijn zeldzaam. Het proefschrift over de toepassing van de bestuurlijke boete van Mein is een goed voorbeeld dat in deze laatste categorie valt. In dit proefschrift staat de toepassing van de bestuurlijke boete centraal en wordt de normativiteit van de bestuurlijke boete niet uit het oog verloren. ${ }^{35} \mathrm{Ik}$ kan me niet aan de indruk onttrekken dat dit proefschrift past in Fijnauts gedachte over de geïntegreerde strafrechtswetenschap, althans de bestuursrechtelijke tegenhanger ervan. Ook Kelk zou dit proefschrift wellicht aanmerken als een voorbeeld van geïntegreerde strafrechtswetenschap aangezien hij heeft aangegeven dat dit concept van belang is voor (de ontwikkeling van) het bestuursstrafrecht. $^{36}$ De bestuurlijke boete is echter geen bestuursstrafrecht, maar bestraffend bestuursrecht en valt daarom - strikt genomen - niet onder de reikwijdte van het concept van de geïntegreerde strafrechtswetenschap. ${ }^{37}$

Voortbouwend op de gedachten die ten grondslag liggen aan het concept van de geïntegreerde strafrechtswetenschap staat in de bestuursrechtelijke criminologie de wisselwerking tussen het handhavende bestuursrecht en de criminologie centraal. Vanuit de criminologische kant dient inzicht te worden verworven in de normatieve structuren van de empirische onderzoeksobjecten en vanuit bestuursrechtelijke kant dient de feitelijke toedracht te worden begrepen van de normatieve problemen, die het voorwerp van onderzoek uitmaken, zo zou Fijnauts visie op de bestuursrechtelijke criminologie kunnen zijn. ${ }^{38}$ Hoewel gelijkenissen bestaan tussen de geïntegreerde strafrechtswetenschap en de bestuursrechtelijke criminologie, bestaat een belangrijk verschil tussen beide. De geïntegreerde strafrechtswetenschap richt zich naast empirisch onderzoek per definitie ook op normatieve kwesties. ${ }^{39}$ Volgens Van de Bunt is een gevaar van de geïntegreerde strafrechtswetenschap erin gelegen dat het sociaalwetenschappelijke begrijpen niet mag worden verward met het normatief-juridisch beoordelen van de feiten. De onderscheidingen tussen strafrecht en criminologie mogen niet vervagen en deze

33 Zie bijvoorbeeld C.L.G.F.H. Albers, 'Bestraffend bestuur 2014. Naar een volwassen bestraffend bestuurs(proces)recht?', in: Boetes en andere bestraffende sancties: een nieuw perspectief? (Preadviezen VAR 2014), Den Haag: Boom Juridische uitgevers 2014, p. 7-108.

34 M.H.A. Kluin, Optic Compliance - Enforcement and Compliance in the Dutch Chemical Industry (diss. Delft), Delft: Ridderprint B.V. 2014.

35 A.G. Mein, De boete uit balans. Het gebruik van de bestuurlijke boete in de praktijk van het financieel toezicht (diss. Rotterdam), Den Haag: Boom Juridische uitgevers 2015.

36 C. Kelk, 'Ten afscheid van Cyrille Fijnaut', DD 1997, p. 5.

37 Dit betekent geenszins dat de term 'bestuursstrafrecht' niet meer wordt gebruikt. Zie bijvoorbeeld A.R. Hartmann \& H.J.B. Sackers, 'Rubriek Bestuursstrafrecht', DD 2016, p. 235, waarin zij aangeven, dat de belangstelling voor het bestuursstrafrecht nog steeds toeneemt.

38 Vgl. Fijnaut 1994, p. 344.

39 Volgens Van Swaaningen gaat dit te ver. Zie R. van Swaaningen, 'Criminologen aan de Maas. Reflecties op het idee van geïntegreerde strafrechtswetenschap', in: A.C. Spapens, M.S. Groenhuijsen \& T. Kooijmans (red.), Universalis (Liber amicorum Cyrille Fijnaut), Antwerpen/Cambridge: Intersentia 2011, p. 261. 
liggen constant op de loer in het concept van de geïntegreerde strafrechtswetenschap. ${ }^{40}$ Hiermee wijst Van de Bunt terecht op een pijnpunt van het concept van de geïntegreerde strafrechtswetenschap. Ten aanzien van de bestuursrechtelijke criminologie is het verrichten van een normatieve analyse naar aanleiding van empirische bevindingen geen vereiste. De bestuursrechtelijke criminologie richt zich namelijk op de empirie van de bestuurlijke rechtshandhaving en is hiermee een criminologische discipline en geen normatieve wetenschap. Dit betekent uiteraard niet dat de bestuursrechtelijke criminologie geen normatieve uitspraken kan doen en uitsluitend - ten aanzien van de juridische wetenschap - reflexief van aard is. Dit laat onverlet dat onderzoek binnen de discipline van de bestuursrechtelijke criminologie wel vooral reflexief van aard is. ${ }^{41}$

De bestuursrechtelijke criminologie richt zich op de empirie van de bestuursrechtelijke handhaving, waaronder de uitoefening van het nalevingstoezicht. Hierin is het verschil gelegen met de bestuursrechtelijke penologie; deze laatste deeldiscipline is uitsluitend gericht op het bestuurlijke sanctie- en maatregelrecht, terwijl de bestuursrechtelijke criminologie is gericht op de bestuurlijke rechtshandhaving in ruime zin. Voor het overige bestaat niet veel verschil tussen de bestuursrechtelijke criminologie en bestuursrechtelijke penologie. De verschillen tussen de geïntegreerde strafrechtswetenschap aan de ene kant en de bestuursrechtelijke criminologie en penologie aan de andere kant zijn - blijkens het voorgaande groter.

\section{Synthese: raakvlakken tussen crimmigratie en bestuursrechtelijke criminologie}

Het concept van crimmigratie is, zoals eerder aangeven, geïntroduceerd door Stumpf en houdt het volgende in: een versmelting van migratierecht en strafrecht, de gelijkaardige wijze waarop migratierecht en strafrecht worden afgedwongen en de procedurele parallellen tussen beide rechtsdomeinen. Het concept is gericht op de samensmelting tussen het vreemdelingenrecht - dat bestuursrechtelijk van aard is - en het strafrecht en de empirische bestudering ervan. ${ }^{42}$ Indien de crimmigratie en de bestuursrechtelijke criminologie met elkaar worden vergeleken, zijn er dan raakvlakken te ontdekken? Het antwoord op deze vraag dient bevestigend te worden beantwoord. Er bestaat een gemeenschappelijke interesse in de bestudering van de bestuurlijke en strafrechtelijke rechtshandhaving. Daarnaast zijn beide concepten 'eigentijds' in de zin dat het recht vanuit een empirisch perspectief kan worden bestudeerd.

Ondanks deze belangrijke overeenkomsten moet eveneens worden gewezen op verschillen tussen beide concepten. Uit de door de redactie van dit tijdschrift

40 H. van de Bunt, 'Corruptie bekeken in zijn context. Overpeinzingen bij de zaak-François en de Vastgoedfraude', in: A.C. Spapens, M.S. Groenhuijsen \& T. Kooijmans (red.), Universalis (Liber amicorum Cyrille Fijnaut), Antwerpen/Cambridge: Intersentia 2011, p. 37.

41 Vgl. Van Swaaningen 2011, p. 261.

42 J.P. van der Leun, M.A.H van der Woude \& S. de Ridder, 'Crimmigratie in de lage landen: smeltende grenzen?', Strafblad 2013, p. 221-228. 
gegeven omschrijving van crimmigratie blijkt naar mijn mening duidelijk dat het een interdisciplinair concept is. De crimmigratie omvat derhalve zowel de juridische als de empirische bestudering van de verstrengeling tussen het immigratieen strafrecht. De bestuursrechtelijke criminologie is daarentegen een empirische discipline, die gericht is op de werking van de bestuurlijke rechtshandhaving in ruime zin. Het tweede belangrijke verschil kan worden gevonden in het feit dat crimmigratie is gericht op het immigratierecht (middels de inzet van en de wisselwerking met het strafrecht). Het object van de bestuursrechtelijke criminologie is ruimer en deze discipline speelt vooral een belangrijke rol in de handhaving van het financieel-economische recht. ${ }^{43}$ Dit laat uiteraard onverlet dat de bestuursrechtelijke criminologie ook van toepassing is op de bestuurlijke handhaving ten aanzien van niet-financieel-economisch recht, zoals de bestuurlijke handhaving van het vreemdelingenrecht. Het derde en laatste verschil hangt nauw samen met de vorige twee verschillen: de bestuursrechtelijke criminologie is uitsluitend gericht op de handhaving van het bestuursrecht, terwijl crimmigratie is gericht niet alleen op handhaving van maar ook op de vervlechting tussen het immigratierecht en het strafrecht. Strafrechtelijke handhaving valt derhalve buiten de reikwijdte van de bestuursrechtelijke criminologie, terwijl dit niet het geval is bij de crimmigratie.

Hoe moet het voorgaande worden beoordeeld? Indien de concepten van crimmigratie en bestuursrechtelijke criminologie met elkaar worden vergeleken, kan niet worden ontkend dat ze gemeenschappelijk kenmerken bevatten. Toch zijn er ook belangrijke verschillen. Het belangrijkste verschil is erin gelegen dat crimmigratie een interdisciplinair concept is, terwijl ik de bestuursrechtelijke criminologie vooral als een empirische discipline zou willen bestempelen. In die zin vertoont crimmigratie meer verwantschap met de geïntegreerde strafrechtswetenschap dan met de bestuursrechtelijke criminologie. Concreet betekent dit het volgende: van wetenschappers die onderzoek verrichten op het gebied van crimmigratie, wordt verwacht dat zij in staat zijn om empirisch onderzoek te verrichten en deze resultaten kunnen vertalen naar een juridisch discours. In de bestuursrechtelijke criminologie staat uitsluitend de empirie van de bestuursrechtelijke handhaving centraal. Het is echter een kwestie van afbakening. Dat de crimmigratie en de bestuursrechtelijke criminologie belangrijke raakvlakken hebben, wordt geillustreerd aan de hand van de bestuurlijke maatregel van de intrekking van het Nederlanderschap in het belang van de nationale veiligheid.

\section{De intrekking van het Nederlanderschap in het belang van de nationale veiligheid}

\subsection{De achtergrond van intrekking van het Nederlanderschap}

In de strijd tegen het terroristische jihadisme wordt het gehele juridische arsenaal aan sancties en maatregelen ingezet om deze vorm van misdaad aan te pakken.

43 B. van der Vorm, 'Bestuursrechtelijke criminologie: relevant voor het bijzondere strafrecht?', TBS\&H 2018, p. 119-121. 
Naast de strafrechtelijke aanpak worden ook (nieuwe) bestuursrechtelijke maatregelen ontwikkeld. In dit verband kan worden gewezen op de Tijdelijke wet bestuurlijke maatregelen terrorismebestrijding en op de mogelijkheid om het Nederlanderschap in te trekken in het belang van de nationale veiligheid. Beide bestuursrechtelijke maatregelen zijn controversieel. Is het bestuursrecht naar aard het geschikte domein om dergelijke vormen van misdaad aan te pakken ${ }^{44}$ Het kabinet is van mening dat dit zeer zeker het geval is en alle registers moeten worden opgetrokken om de nationale veiligheid te beschermen.

Tegen deze achtergrond is een wetsvoorstel ontwikkeld dat ertoe strekt om het mogelijk te maken het Nederlanderschap in te trekken wegens deelname aan een terroristische organisatie zonder dat daarvoor een voorafgaande strafrechtelijke veroordeling is vereist. Met het wetsvoorstel tot wijziging van de Rijkswet op het Nederlanderschap in verband met het intrekken van het Nederlanderschap in het belang van de nationale veiligheid heeft het kabinet gehoor gegeven aan het Actieprogramma Integrale Aanpak Jihadisme. ${ }^{45}$ Door het kabinet wordt benadrukt dat het strafrecht een zeer belangrijk instrument blijft om terrorisme te bestrijden, maar het strafrecht schiet - in de ogen van het kabinet - tekort in de zin dat het niet kan voorkomen dat een uitreiziger die geoefend is in het gebruik van geweld of het gebruik van geweld heeft gefaciliteerd, terugkeert naar Nederland. ${ }^{46}$ Met het wetsvoorstel wordt beoogd om het mogelijk te maken dat het Nederlanderschap wordt ingetrokken in combinatie met een ongewenstverklaring als vreemdeling, zodat de legale terugkeer naar het Koninkrijk der Nederlanden wordt bemoeilijkt. Vanwege de intrekking van het Nederlanderschap verliest de betrokkene het recht op toegang tot het Nederlandse grondgebied. Als vreemdeling heeft de betrokkene eveneens geen toegang tot Nederland, omdat hij ook tot ongewenste vreemdeling is verklaard. ${ }^{47}$ Deze mogelijkheid van intrekking van nationaliteit is beperkt tot personen met een dubbele nationaliteit. Hoewel dit wetsvoorstel is bekritiseerd, ${ }^{48}$ is het inmiddels aangenomen door de Eerste Kamer en reeds in werking getreden. ${ }^{49}$ De belangrijkste wijziging heeft betrekking op de wijziging van artikel 14 Rijkswet op het Nederlanderschap. Uit het derde lid van deze bepaling blijkt dat de minister van Justitie en Veiligheid het Nederlanderschap kan intrekken van een persoon die de leeftijd van zestien jaren heeft bereikt en die zich vrijwillig in vreemde krijgsdienst begeeft van een staat die betrokken is bij gevechtshandelingen tegen het Koninkrijk dan wel tegen een bondgenootschap waarvan het Koninkrijk lid is. Daarnaast blijkt uit artikel 14,

44 P.S.M. Rademakers, 'Behoren de bestuurlijke maatregelen tegen jihadisme in het strafrecht? Is het strafrecht het ultieme remedium in de strijd tegen terrorisme?', TPWS 2015/17.

45 Kamerstukken II 2015/16, 34356 (R2064), nr. 3, p. 1.

46 Kamerstukken II 2015/16, 34356 (R2064), nr. 3, p. 3.

47 Kamerstukken II 2015/16, 34356 (R2064), nr. 3, p. 4.

48 Zie o.m. B. van der Vorm, 'De bestuurlijke aanpak van het jihadisme. De intrekking van het Nederlanderschap in het belang van de nationale veiligheid als (preventieve) verbanning', PROCES 2016, p. 17-28.

49 Rijkswet van 10 februari 2017, houdende wijziging van de Rijkswet op het Nederlanderschap in verband met het intrekken van het Nederlanderschap in het belang van de nationale veiligheid, Stb. 2017, 52. 
vierde lid, Rijkswet op het Nederlanderschap, dat de minister van Justitie en Veiligheid in het belang van de nationale veiligheid het Nederlanderschap kan intrekken van een persoon die de leeftijd van zestien jaren heeft bereikt en die zich buiten het Koninkrijk bevindt, indien uit zijn gedragingen blijkt dat hij zich heeft aangesloten bij een organisatie die door de minister, in overeenstemming met het gevoelen van de Rijksministerraad, is geplaatst op een lijst van organisaties die deelnemen aan een nationaal of internationaal gewapend conflict, en een bedreiging vormen voor de nationale veiligheid.

De rechtsbescherming is geregeld in hoofdstuk 7a van de Rijkswet op het Nederlanderschap. Tegen een besluit tot intrekking van het Nederlanderschap staat rechtstreeks beroep open bij de Rechtbank Den Haag, zo blijkt uit artikel 22a, eerste lid, Rijkswet op het Nederlanderschap. Uiterlijk op de achtentwintigste dag na de bekendmaking van een besluit tot intrekking van het Nederlanderschap stelt de minister de rechtbank hiervan in kennis, tenzij degene die het betreft voordien zelf beroep heeft ingesteld (artikel 14, vierde lid, Rijkswet op het Nederlanderschap). De toevoeging van een raadsman kan op eigen initiatief van de belanghebbende, maar dit is niet noodzakelijk. De wettige vertegenwoordiger of de bijzondere gemachtigde van de belanghebbende zijn eveneens bevoegd een of meer raadslieden te kiezen (artikel 22, tweede lid, Rijkswet op het Nederlanderschap). Als de belanghebbende zijn wil niet kan doen blijken en hij geen wettelijke vertegenwoordiger of bijzondere gemachtigde heeft, dan is zijn echtgenoot of de meest gerede van zijn in het Koninkrijk verblijvende bloed- of aanverwanten, tot de vierde graad ingesloten, tot die keuze bevoegd (artikel 22, derde lid, Rijkswet op het Nederlanderschap). In het uiterste geval wordt een raadsman aan de vreemdeling toegewezen (artikel 22b, vijfde lid, Rijkswet op het Nederlanderschap).

\subsection{Twee recente uitspraken over de rechtmatigheid van een opgelegde bestuurlijke maatregel}

De rechtsbescherming die in titel 7a van de Rijkswet op het Nederlanderschap wordt geboden, wijkt af van de gebruikelijke rechtsgang in het bestuursprocesrecht. Het uitgangspunt in het bestuursprocesrecht is namelijk dat een belanghebbende na de bekendmaking van een besluit zelfstandig dan wel bij een gemachtigde beroep instelt. De regeling van artikel 22a Rijkwet op het Nederlanderschap laat echter de mogelijkheid bestaan dat de belanghebbende niet op de hoogte is van het intrekkingsbesluit en de daartegen ingestelde procedure en voorts geen contact heeft gehad met de door de rechtbank toegevoegde raadsman of de door bloedverwanten gekozen raadsman. In twee recente zaken is deze problematiek aan de orde geweest.

In de eerste zaak is de belanghebbende een persoon die is geboren op 16 juni 1993 in Marokko en de Marokkaanse nationaliteit bezit. Op 29 november 1996 is aan hem daarnaast het Nederlanderschap verleend. ${ }^{50} \mathrm{Hij}$ is bij verstek veroordeeld tot zes jaren gevangenisstraf voor deelneming aan een organisatie die tot oogmerk heeft het plegen van terroristische misdrijven (ECLI:NL:RBDHA: 
2016:8464). De rechtbank heeft onder meer vastgesteld dat B zich vanaf 25 december 2012 tot en met 27 mei 2014 in het strijdgebied in Syrië en/of Irak bevond en zich heeft aangesloten bij IS(IS), Jabhat al-Nusra of een gelieerde terroristische, gewelddadige, jihadistische strijdgroep. De minister van Justitie en Veiligheid heeft bij besluiten van 11 september 2017, bekendgemaakt door publicatie in de Staatscourant van 13 september 2017, het Nederlanderschap van deze persoon ingetrokken en hem ongewenst verklaard. Op 3 oktober 2017 heeft de door de ouders van de belanghebbende aangezochte advocaat beroep ingesteld tegen de besluiten van 11 september 2017.51

De tweede zaak vertoont een grote gelijkenis met de zojuist besproken zaak. De belanghebbende is geboren in Roermond en heeft de Marokkaanse nationaliteit en Nederlandse nationaliteit. Op 10 december 2015 is hij in het Context-proces door de Rechtbank Den Haag (ECLI:NL:RBDHA:2015:14365) bij verstek veroordeeld tot zes jaar gevangenisstraf voor deelneming aan een organisatie die tot oogmerk heeft het plegen van terroristische misdrijven. De rechtbank heeft onder meer vastgesteld dat Z op 24 maart 2013 is uitgereisd naar Syrië, tot in ieder geval oktober 2014 heeft deelgenomen aan de gewapende jihadstrijd en deze strijd tevens heeft gefaciliteerd door geld onder de strijders te verdelen, heeft deelgenomen aan een trainingskamp en zich heeft aangesloten bij ISIS. Daarnaast heeft hij een substantiële rol gespeeld bij het faciliteren van Haagse jongeren die zijn afgereisd naar Syrië. De minister van Justitie en Veiligheid heeft bij besluiten van 11 september 2017, bekendgemaakt door publicatie in de Staatscourant van 13 september 2017, het Nederlanderschap van Z ingetrokken en hem ongewenst verklaard. Een advocaat heeft zich bij brief van 5 oktober 2017 aangeboden als amicus curiae en de rechtbank heeft aan de Raad voor Rechtsbijstand een last tot toevoeging verstrekt op naam van deze advocaat. ${ }^{52}$

In beide zaken wordt door de raadsman betoogd dat geen contact is geweest met de belanghebbende en de belanghebbende zichzelf niet kan verdedigen. Door de rechtbank wordt het aangevoerde opgevat als een beroep op het Unierechtelijke beginsel van effectieve rechtsbescherming, zoals bedoeld in artikel 47 Handvest voor de grondrechten van de Europese Unie. Door de rechtbank wordt in beide zaken vastgesteld dat sprake is van beperkingen van het beginsel van effectieve rechtsbescherming. De beperkingen van het beginsel van effectieve rechtsbescherming zijn echter niet gerechtvaardigd. De beperkingen maken immers een inbreuk op de kernwaarden van eerlijk proces, waarbij de verweerder - in casu de staatssecretaris van Justitie en Veiligheid - de noodzaak van de inbreuk niet heeft aangetoond. De rechtbank verklaart artikel 22a, derde lid, Rijkswet op het Nederlanderschap onverbindend wegens strijdigheid met artikel 47 Handvest voor de grondrechten van de Europese Unie, hetgeen betekent dat een wettelijke

51 Rechtbank Den Haag 26 juni 2018, ECLI:NL:RBDHA:2018:7615, Module Nationaliteitsrecht 2018/886.

52 Rechtbank Den Haag 26 juni 2018, ECLI:NL:RBDHA:2018:7617, JV 2018/159. 
grondslag voor de ingediende beroepsschriften ontbreekt. De beroepschriften worden door de rechtbank niet-ontvankelijk verklaard. ${ }^{53}$

Wat zijn nu de gevolgen van deze uitspraken? Het besluit van de minister blijft onveranderd, waardoor de twee belanghebbenden Nederland niet mogen betreden en ook geen rechten hebben die verbonden zijn met het Nederlanderschap. De betrokkenen kunnen het besluit evenwel aanvechten na het verstrijken van de beroepstermijn.

\subsection{De crimmigratie en de intrekking van het Nederlanderschap}

Welke bijdrage kan de crimmigratie leveren in de kwestie omtrent de intrekking van het Nederlanderschap in het belang van de nationale veiligheid? Van Noorloos heeft terecht aangegeven dat het beleid ter voorkoming van de terugkeer van Syriëgangers op lange termijn mogelijk schadelijk is. ${ }^{54}$ De crimmigratie kan de problematiek van de intrekking van het Nederlanderschap op verschillende wijzen benaderen. Ten eerste kan worden gewezen op een juridische benadering. Uit de zojuist besproken uitspraken blijkt dat het een en ander schort aan de geboden rechtsbescherming die is neergelegd in titel 7a Rijkswet op het Nederlanderschap. Dit betekent dat het noodzakelijk is om de thans geregelde rechtsbescherming te herwaarderen. Hier is zeer zeker ook een rol weggelegd voor de crimmigratie. Voorts kan worden gewezen op juridisch onderzoek naar de afstemming tussen bestuursrecht en strafrecht ten aanzien van de handhaving van het intrekkingsbesluit en de ongewenstverklaring. Ook hier liggen mogelijkheden voor de crimmigratie. Ten tweede dient het 'blijf-maar-daar'-beleid aan een kritische analyse te worden onderworpen. De juridische procedure ten aanzien van de intrekking van het Nederlandschap kan niet worden losgezien van de politiek-maatschappelijke context waarin hij tot stand komt.55 Ook ten aanzien van een sociaalwetenschappelijke bestudering van de praktijk van de intrekking van het Nederlanderschap liggen er kansen voor de crimmigratie. Zowel vanuit een juridisch als empirisch perspectief kan de problematiek van de intrekking van het Nederlandschap worden bestudeerd, waardoor de crimmigratie hier een zeer wezenlijke bijdrage aan kan leveren.

\subsection{De bestuursrechtelijke criminologie en de intrekking van het Nederlanderschap}

De bestuursrechtelijke criminologie kan eveneens een bijdrage leveren aan de kwestie van de intrekking van het Nederlanderschap. Vooreerst dient te worden opgemerkt dat de invloed van deze discipline naar mijn mening geringer zal zijn dan de crimmigratie. Dit wordt enerzijds veroorzaakt door het feit dat de bestuursrechtelijke criminologie - mijns inziens - is te beschouwen als een empirische wetenschap, ten gevolge waarvan normatieve analyses achterwege kunnen blijven. Anderzijds is de bestuursrechtelijke criminologie gericht op de werking

53 Rechtbank Den Haag 26 juni 2018, ECLI:NL:RBDHA:2018:7615, Module Nationaliteitsrecht 2018/886, r.o. 8.4; Rechtbank Den Haag 26 juni 2018, ECLI:NL:RBDHA:2018:7617, JV 2018/159, r.o. 8.4.

54 M. van Noorloos, 'Syriëgangers' en hun terugkeer naar Nederland', Crimmigratie \& Recht 2018, p. 58.

55 Van der Woude 2018, p. 5. 
van bestuurlijke rechtshandhaving, hetgeen ruimer is dan het object van de crimmigratie. Ten aanzien van de intrekking van het Nederlanderschap kunnen de crimmigratie en de bestuursrechtelijke criminologie elkaar ontmoeten op dit punt: sociaalwetenschappelijk onderzoek naar de opvattingen en afwegingen van de bestuurlijke overheid ten aanzien van de toepassing van de intrekking van het Nederlandschap. De beide concepten komen elkaar - althans in mijn opvatting in eerste instantie niet tegen in juridische analyses over de verstrengeling tussen het bestuursrecht (immigratierecht) en het strafrecht.

\section{Conclusie}

De gedachte dat misdaad uitsluitend dient te worden bestreden middels de inzet van het strafrecht is reeds achterhaald. Ook het bestuursrecht wordt ingezet als handhavingsinstrument. Een goed voorbeeld hiervan is de integrale aanpak van het jihadisme. Strafrechtelijke en bestuursrechtelijke instrumenten worden gecombineerd om zo effectief mogelijk deze vorm van misdaad aan te pakken. In deze bijdrage is aan de hand van de bestuurlijke maatregel van de intrekking van het Nederlanderschap onderzocht wat de overeenkomsten en verschillen zijn tussen crimmigratie en bestuursrechtelijke criminologie en op welke wijze zij elkaar kunnen aanvullen. Op het eerste gezicht lijken beide concepten veel verwantschap met elkaar te vertonen. Een nadere analyse laat echter zien dat de crimmigratie meer past in het concept van de geïntegreerde strafrechtswetenschap dan dat zij overeenkomsten laat zien met de bestuursrechtelijke criminologie. De crimmigratie kan worden beschouwd als een interdisciplinair concept, terwijl de bestuursrechtelijke criminologie moet worden aangemerkt als een empirische discipline. Hier schuilt een belangrijk - en wat mij betreft doorslaggevend - verschil tussen de crimmigratie en de bestuursrechtelijke criminologie. Desalniettemin kunnen beide concepten elkaar aanvullen in de sociaalwetenschappelijke bestudering van de uitvoeringspraktijk van het immigratierecht. 